\title{
Annual and Seasonal Trends of Solar Radiation in Athens, Greece
}

\author{
Harry D. Kambezidis
}

\author{
Atmospheric Research Team, Institute of Environmental Research and Sustainable Development, National \\ Observatory of Athens, GR-11810 Athens, Greece
}

\begin{abstract}
This study deals with the solar radiation levels recorded at the Actinometric Station of the National Observatory of Athens, focusing on the trends of the global and diffuse horizontal irradiances in the period of 1992-2017 (26 years). The analysis shows that the annual global radiation time series over Athens in the above period presents a positive trend $(+0.40 \% /$ decade and $+2.38 \%$ /decade for all and clear skies, respectively), while its diffuse counterpart shows negative trend $(-5.19 \% / d e c a d e$ and $-6.77 \%$ /decade for the same sky conditions, respectively) during the same period. Also, the seasonal trends of both solar radiation components are examined. The global horizontal radiation shows positive trends in summer $(+1.85 \% /$ decade and $+2.10 \% /$ decade under all and clear skies, respectively), while a negative trend is calculated in the winter season $(-2.46 \% /$ decade and $-1.99 \% /$ decade for the same sky conditions, respectively). In the case of the diffuse solar radiation there are found negative trends in both seasons and both sky conditions. These findings confirm a recovery in the solar radiation levels over Athens in the recent 26 years.
\end{abstract}

Keywords: Solar radiation, Global horizontal irradiance, Diffuse horizontal irradiance, trends, Athens, Greece.

\section{INTRODUCTION}

Solar radiation reaching the surface of the Earth is the primary source for life as it controls various fields [1-3]. The exploitation of solar energy for various applications started almost twenty years ago mainly for PV installations [4]. Fluctuations of solar radiation are caused by changes in atmospheric constituents (e.g., [5]), by variations in cloud cover (e.g., [6]), as well as by changes in the Sun-Earth geometry (Milankovitch theory).

In view of the above, solar radiation undergoes variations at scales as short as seasons and as long as decades (e.g., [7]). The short-term variations are mainly attributed to the rotation of the Earth around the Sun, and the long-term ones to changes in atmospheric composition. In this context, the so-called "global dimming/brightening effect" refers to a decrease/increase in the solar radiation levels [7] that has serious implications in the Earth's climate (e.g., [8]).

There are various studies in the international literature that refer to the solar radiation variations at different sites worldwide and differing periods. A decline in the solar radiation intensity over North America and Europe has been found in the period of 1960-1980, and a recovery afterwards of $\sim+1.50$ $\mathrm{Wm}^{-2} /$ decade to $+2.40 \mathrm{Wm}^{-2} /$ decade in $1990-2000$ [9, 10]. However, solar dimming continues to exist over India and Southeast Asia [11-13] estimated a decline in

*Address correspondence to this author at the Atmospheric Research Team, Institute of Environmental Research and Sustainable Development, National Observatory of Athens, GR-11810 Athens, Greece;

Tel: +30 210 3490119; E-mail: harry@noa.gr global solar radiation of $-2.30 \mathrm{Wm}^{-2} /$ decade over China (an average value from 459 stations in the period 19612000). Very few studies, though, cover several years beyond 2000s (e.g., [14]). On the other hand, the Mediterranean area, as a crossroad of atmospheric aerosols, has been investigated only by [15] in the period 1979-2012.

A recent study by Kazadzis et al. [16] examined the variation of the global horizontal radiation levels over Athens and found a trend of $+0.80 \% /$ decade in the period $1983-2012$ or a $+0.40 \%$ /decade in $1900-2012$. Kambezidis $[17,18]$ repeated calculations of the global solar irradiance trend and found a contradictory result $(+0.41 \%$ /decade in 1992-2017); he attributed this discrepancy to the different periods examined in the studies.

The present work analyses global horizontal and diffuse horizontal irradiance data for Athens in the period of the last 26 years (1992-2017). The structure of the paper is as follows. Section 2 presents the data used in the study (i.e., the data collection in Subsection 2.1, the data processing in Sub-section 2.2, the methodology in Sub-section 2.3). Section 3 presents the results of the study (i.e., the trend in the global radiation in Sub-section 3.1, the trend in the diffuse solar radiation in Sub-section 3.2). Section 4 presents the main conclusions of the study. Acknowledgments and References follow.

\section{MATERIALS AND METHODS}

\subsection{Data Collection}

The Actinometric Station of the National Observatory of Athens (ASNOA) is a unique organized 
solar radiation platform in Greece $\left(37.97^{\circ} \mathrm{N}, 22.72^{\circ} \mathrm{E}\right.$, $107 \mathrm{~m} \mathrm{amsl}$ ) in terms of long-term records and completeness in the measuring solar components. It is situated on the Hill of Pnyx, very close to the Acropolis of Athens. It started its operation in 1953 by measuring global horizontal radiation. In the progress of time, ASNOA was enriched with other radiometric equipment for measuring additional solar radiation components, e.g., diffuse horizontal radiation. The parameters analysed in this work are the global horizontal irradiance $\left(H_{g}\right.$ in $\left.\mathrm{Wm}^{-2}\right)$, and the diffuse one $\left(H_{d}\right.$ in $\mathrm{Wm}^{-}$ ${ }^{2}$ ). Both parameters are recorded at ASNOA by a data logger, which performs measurements every $20 \mathrm{~s}$. The logger calculates 1-min averages from three 20-s samples and stores them. The 1-min values are further processed off-line following a quality-control test (QCT) shown in Table 1 , where $H_{b}$ is the direct horizontal irradiance $\left(H_{b}=H_{g}-H_{d}\right.$, in $\left.\mathrm{Wm}^{-2}\right) ; H_{g, e x}$ is the extraterrestrial global solar horizontal irradiance given by [19]:

$H_{g, e x}=S \cdot H_{g, o} \cdot \sin \gamma$,

where the solar constant $\left(H_{g, o}\right)$ is $1360.8 \mathrm{Wm}^{-2}$ (the latest value according to [20], and $\gamma$ the solar altitude; a precise expression for $S$ is given by [21]:

$\mathrm{S}=1.00011+0.034211 \cdot \cos \tau+0.00128 \cdot \sin \tau+$

$0.000719 \cdot \cos (2 \tau)+0.000077 \cdot \sin (2 \tau)$

$\tau=2 \pi \cdot(J-1) / 365$,

where $J$ is the day number of the year $(J=1$ for 1 January, $J=365$ for 31 December, and $J=366$ for 31 December on leap years).

1-min values of the $H_{g}$ and $H_{d}$ components were used in this study from the ASNOA records, covering the period of 1992-2017 (26 years).

Table 1: QCTs for the 1-min Average Values of the Irradiance Parameters at ASNOA [22]. Those Solar Radiation Values not Obeying any of the Criteria were Rejected

\begin{tabular}{|c|}
\hline$H_{d}<1.1 H_{g}$ \\
\hline$H_{g}<1.2 H_{g, e x}$ \\
\hline$H_{d}<0.8 H_{g, e x}$ \\
\hline$H_{b}<H_{g, e x}$ \\
\hline$H_{g} \geq 10 \mathrm{Wm}^{-2}$ (lower detection limit of pyranometers) \\
\hline$\gamma \geq 5^{\circ}$ (avoiding the pyranometer's cosine effect) \\
\hline
\end{tabular}

Both $H_{g}$ and $H_{d}$ are recorded at ASNOA with Eppley PSP pyranometers since 1987; these pyranometers are regularly calibrated against a prototype Eppley PSP one that is calibrated from time to time at PMOD/WRC, Davos, Switzerland. The diffuse horizontal irradiance is measured with the aid of an Eppley shadow-band device; its measurements are corrected offline for the shadow-band effect by using the Littlefair (1989) methodology.

\subsection{Data Processing}

The first step in the data processing was the quality control of the data time series of both solar radiation components at the 1-min level. After that, the 1-min radiation values were converted into hourly averages and then into monthly means. The 312 monthly values (26 years $\times 12$ months) of each radiation parameter were tested for inhomogeneity, but no important findings came up. Seasonality was also extracted from the monthly time series of each parameter as solar radiation is subject to an annual cycle. The methodology for removing seasonality in a time series can be found in Wikipedia (https://en.wikipedia.org/wiki/Seasonality, accessed on 31 May 2018). After that, deseasonalised monthly values for both $H_{g}$ and $H_{d}$ data series were derived. From these monthly values, deseasonalised seasonal and annual values were estimated. In this study, the seasons of winter (December, January, February) and summer (June, July, August) were considered as being associated with low and high radiation levels, respectively.

\subsection{Methodology}

The data processing described in Sub-section 2.2 was applied to the $H_{g}, H_{d}$ data under all-sky conditions. In order to isolate the $H_{g}$ and $H_{d}$ values under clear-sky conditions, such cases were derived upon the criterion of $H_{b, n} \geq 120 \mathrm{Wm}^{-2}$, where $H_{b, n}$ is the direct-normal solar radiation:

$H_{b, n}=\frac{H_{g}-H_{d}}{\sin \gamma}$

The above equation was applied to all remained 1min $H_{g}$ and $H_{d}$ values after passing through QCT (Table 1); therefore, a separate data base with the two solar parameters for the clear-sky cases was formed. The all-sky $H_{g}$ and $H_{d}$ values were those that remained after the application of the QCT without any additional criterion imposed on the measurements. Therefore, two different data bases were created, one for the all-sky case and another for the clear-sky one. The homogeneity test was applied to both solar radiation components in the two data bases, which did not show 
important findings. Seasonal and annual averages were then calculated from both data bases and both solar radiation components.

\section{RESULTS AND DISCUSSION}

\subsection{Trends in $H_{g}$}

Figure 1 shows the annual $H_{g}$ averages under alland clear-sky conditions. The linear fits to both plots show the annual trends of $H_{g}$ under the mentioned cloudiness. These fits have relations given by the equations:

$H_{g, a}=30.45+0.17$ year

$H_{g, c}=-1633.15+1.01$ year

where the subscripts a, c refer to all- and clear-sky conditions, respectively. The parameter year refers to any year of the period 1992-2017.

Considering the decade 1992-2001, and applying its end years to Eq. (3a), taking the difference $H_{g, a 2001}$ $H_{g, a 1992}$, and dividing it by the 1992-2017 mean = $370.12 \mathrm{Wm}^{-2}$, it is found that $H_{g}$ has a trend of $+0.40 \% /$ decade or $+0.04 \% /$ year over the studied period. These percentages are related to trends of $+1.53 \mathrm{Wm}^{-2} /$ decade or $+0.15 \mathrm{Wm}^{-2} /$ year, respectively. For the case of clear skies, the trends become $+2.38 \% /$ decade ( $\approx+0.24 \% /$ year $)$ and $+9.09 \mathrm{Wm}^{-}$ ${ }^{2} /$ decade $\left(\approx+0.91 \mathrm{Wm}^{-2} /\right.$ year ), if the average $=382.21$ $\mathrm{Wm}^{-2}$ is taken into account.
Table 2 presents a comparison of the $H_{g}$ trend between this study and that from other similar works. One may observe the different periods examined in the studies mentioned as well as the discrepancies in the trends themselves. The latter may be attributed to two reasons: (i) the different periods over which the trends are estimated, and (ii) the spatial average of $H_{g}$ in some cases in contrast to the point averages considered in the present study and in Kambezidis (2018b).

Figure 2 shows the trend of the $H_{g}$ time series for winter and summer under all-sky conditions over Athens during the period of the study. The linear fits to both plots show the seasonal trends of $H_{g}$ under the mentioned cloudiness. These fits have relations given by the equations:

$$
\begin{aligned}
& H_{g, a, w}=1875.20-0.79 \text { year } \\
& H_{g, a, s}=-1596.65+1.04 \text { year }
\end{aligned}
$$

The subscripts $\mathrm{w}, \mathrm{s}$ refer to winter/summer, respectively. Again, considering the decade 19922001, applying the end years to Eq. (4a), taking the

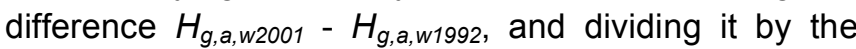
mean $=288.77 \mathrm{Wm}^{-2}$, it is found that $H_{g}$ has a winter trend over the studied period of $-2.46 \% /$ decade or $0.25 \% / y e a r$. These percentages correspond to trends of $-7.11 \mathrm{Wm}^{-2} /$ decade or $-0.71 \mathrm{Wm}^{-2} /$ year, respectively. By repeating the above calculations for the summer season in Eq. (4b), it is found that the $H_{g}$ time series

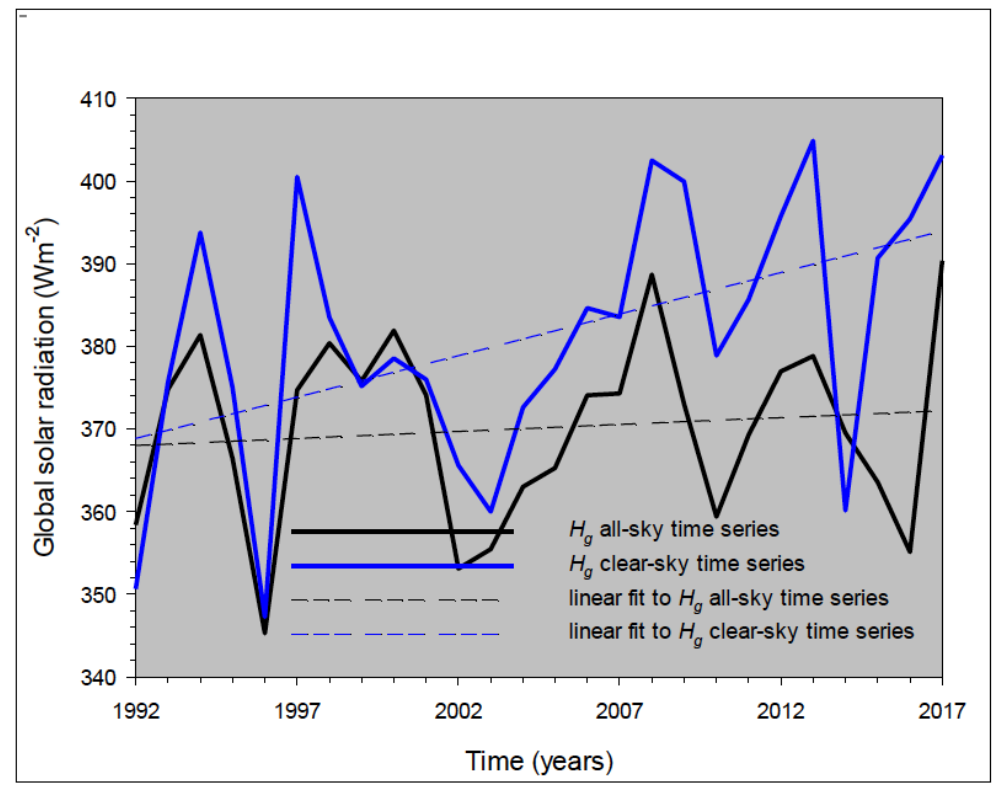

Figure 1: Variation of the annual mean $H_{g}$ values under all- and clear-sky conditions in Athens over the period 1992-2017. The linear best-fit expressions are given by Eqs. (3a) and (3b) for all- and clear-skies, respectively. 
Table 2: Trends in the Annual $\boldsymbol{H}_{g}$ Mean Values under all- and Clear-Sky Conditions for Various Sites in Europe/Asia and Periods. A Question mark (?) Implies an Unmeasured Value

\begin{tabular}{|c|c|c|c|}
\hline Cloudiness Conditions & $\begin{array}{c}\text { Trend in } H_{g} \\
\% / \text { decade }\left(\mathrm{Wm}^{-2} / \text { decade }\right)\end{array}$ & Reference & Period (region) \\
\hline all skies & $+0.40(+1.53)$ & present work & 1992-2017 (Athens, Greece) \\
\hline clear skies & $+2.38(+9.09)$ & & \\
\hline all skies & $+0.41(+1.50)$ & {$[17,18]$} & \\
\hline clear skies & $+2.36(+9.09)$ & & \\
\hline all skies & $+0.80(?)$ & {$[16]$} & 1983-2012 (Athens, Greece) \\
\hline all skies & $+0.40(?)$ & & 1900-2012 (Athens, Greece) \\
\hline all skies & $+3.30(?)$ & {$[23]$} & 1993-2011 (Thessaloniki, Greece) \\
\hline all skies & $?(+1.81)$ & {$[24]$} & 1966-2015 (The Netherlands) \\
\hline all skies & $\begin{array}{l}?(+3.70) \\
?(+2.50) \\
?(+3.50) \\
?(+3.90) \\
?(+2.30)\end{array}$ & {$[14]$} & $\begin{array}{c}1986-2012 \text { (C. Europe) } \\
1986-2012 \text { (N. Europe) } \\
1986-2012 \text { (E. Europe) } \\
1986-2012 \text { (S. Europe) } \\
1986-2012 \text { (NW. Europe) }\end{array}$ \\
\hline all skies & $\begin{array}{l}?(-1.00) \\
?(+4.70) \\
?(+2.80) \\
?(+3.50)\end{array}$ & {$[25]$} & $\begin{array}{c}1994-2010 \text { (Balearic Ils., Spain) } \\
\text { 1985-2010 (Mallorca, Spain) } \\
\text { 1983-2010 (W. Europe) } \\
1983-2010 \text { (C. Europe) }\end{array}$ \\
\hline all skies & $?(+0.60)$ & {$[15]$} & 1979-2012 (Mediterranean) \\
\hline all skies & $?(+2.10)$ & [26] & $?$ (E. Mediterranean) \\
\hline all skies & $?(+1.10)$ & [9] & 1987-2002 (Europe) \\
\hline all skies & $+3.20(?)$ & [27] & 1980-2007 (Europe) \\
\hline all skies & $\begin{array}{l}?(+7.70) \\
?(+6.00)\end{array}$ & [28] & $\begin{array}{l}1983-2013 \text { (N. Italy) } \\
1983-2013 \text { (S. Italy) }\end{array}$ \\
\hline clear skies & $?(+7.60$ to +7.90$)$ & & 1986-2013 (from N. Italy to S. Italy) \\
\hline all skies & $+2.50(?)$ & [29] & 1990-2016 (NW. Italy) \\
\hline all skies & (?) $(+1.90$ to +3.70$)$ & {$[30]$} & 1992-2015 (Europe, excluding Balkans) \\
\hline all skies & $\begin{array}{l}+2.4(+3.0) \\
+1.9(+2.9) \\
+1.6(+1.7) \\
+2.7(+5.0) \\
+2.4(+2.6) \\
+2.0(+2.6) \\
+2.2(+3.3) \\
+2.7(+2.8) \\
+3.0(+5.7) \\
+1.8(+2.0)\end{array}$ & {$[31]$} & $\begin{array}{c}1983-2015 \text { (CE. Europe) } \\
1983-2015 \text { (CW. Europe) } \\
1983-2015 \text { (NW. Europe) } \\
1983-2015 \text { (S. Europe) } \\
1983-2015 \text { (N. Europe) } \\
1992-2015 \text { (CE. Europe) } \\
1992-2015 \text { (CW. Europe) } \\
1992-2015 \text { (NW. Europe) } \\
1992-2015 \text { (S. Europe) } \\
1992-2015 \text { (N. Europe) }\end{array}$ \\
\hline all skies & $\begin{array}{l}?(+4.20) \\
?(+7.10) \\
?(+4.50)\end{array}$ & {$[32]$} & $\begin{array}{c}1989-2004 \text { (Mediterranean) } \\
\text { 1985-2000 (E. Europe) } \\
\text { 1985-2001 (Europe) }\end{array}$ \\
\hline all skies & $?(-2.30)$ & [13] & $1961-2000$ (China, average of 459 stations) \\
\hline all skies & $?(-5.40)$ & {$[12]$} & after 2000 (S. Asia) \\
\hline
\end{tabular}

has a trend of $+1.85 \% /$ decade $(\approx+0.19 \% /$ year $)$ or +9.36 that $=488.95 \mathrm{Wm}^{-2}$. $\mathrm{Wm}^{-2} /$ decade $\left(\approx+0.94 \mathrm{Wm}^{-2} /\right.$ year), taking into account 


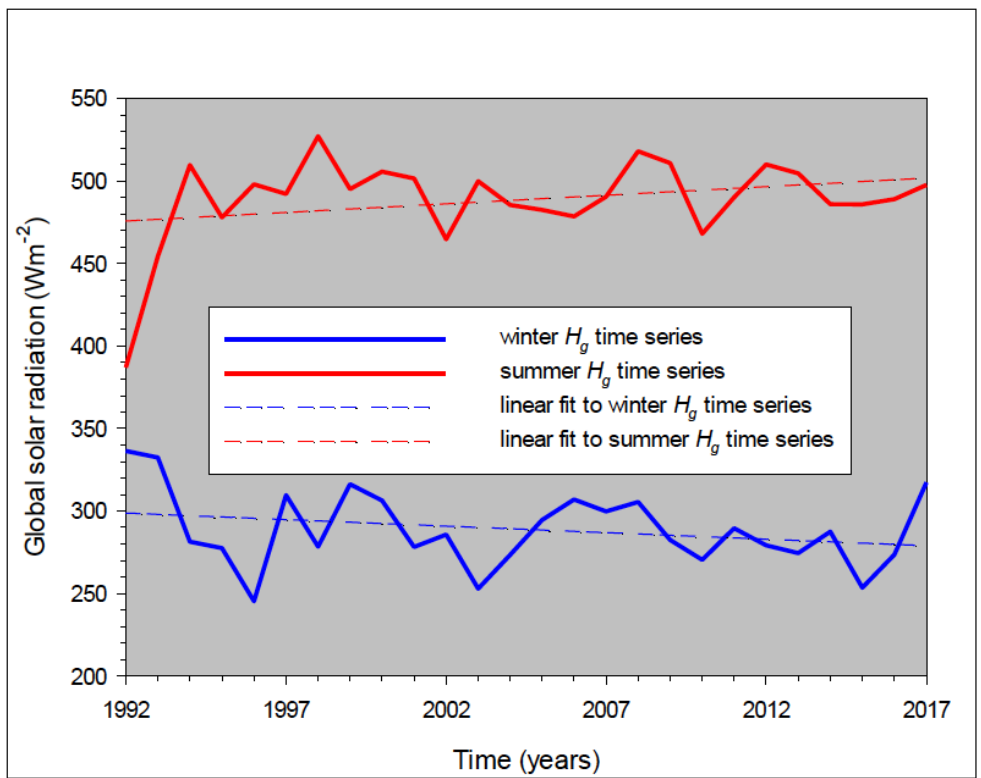

Figure 2: Variation of the winter/summer mean $H_{g}$ values under all-sky conditions in Athens over the period 1992-2017. The linear best-fit expressions are given by Eqs. (4a) and (4b) for winter and summer, respectively.

For the clear-sky cases, Figure 3 shows the trend of the $H_{g}$ time series for the winter and summer seasons over Athens. The linear fits to both plots show the seasonal trends of $H_{g}$ under the mentioned cloudiness. These fits have relations given by the equations:

$H_{g, c, w}=1614.49-0.66$ year

$H_{g, c, s}=-1859.62+1.18$ year

Again, considering the decade 1992-2001, applying the end years to Eq. (5a), taking the difference $H_{g, c, w 2001}$

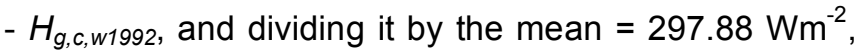
it is found that $H_{g}$ has a winter trend over the studied period of $-1.99 \% /$ decade or $\approx-0.20 \% /$ year. These percentages correspond to trends of $-5.94 \mathrm{Wm}^{-}$ ${ }^{2} /$ decade or $\approx-0.59 \mathrm{Wm}^{-2} /$ year, respectively. By repeating the above calculations for the summer season in Eq. (5b), it is found that the $H_{g}$ time series has a trend of $+2.10 \% /$ decade $(+0.21 \% /$ year $)$ or +10.62 $\mathrm{Wm}^{-2} /$ decade $\left(\approx+1.06 \mathrm{Wm}^{-2} /\right.$ year $)$. Note that $=505.17$ $\mathrm{Wm}^{-2}$

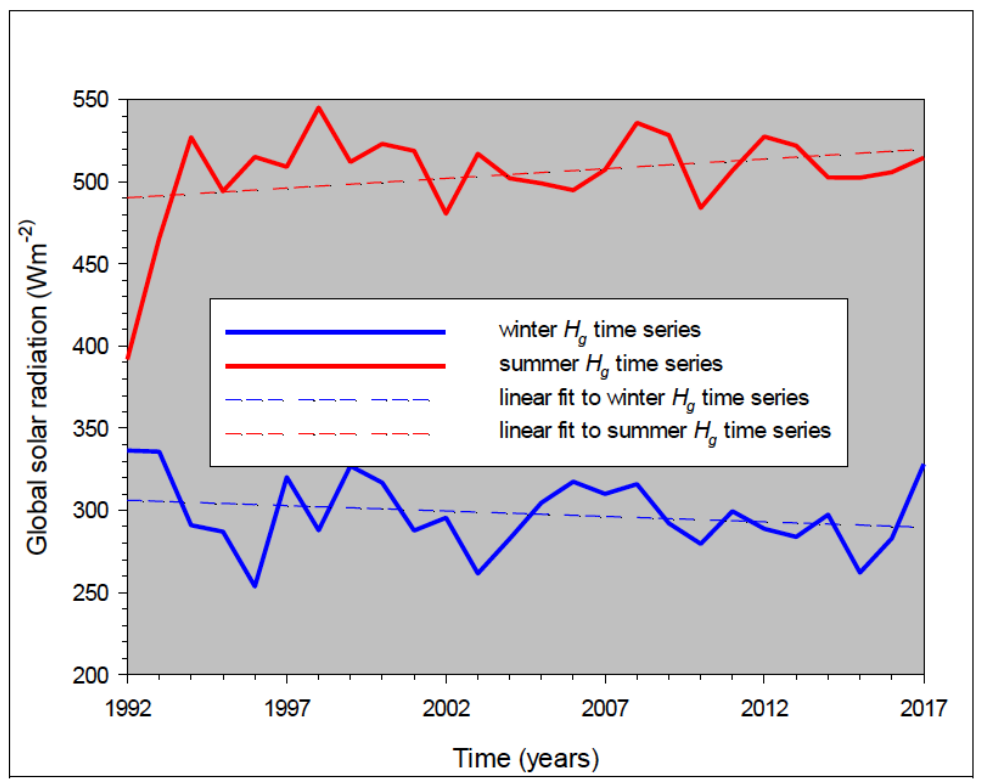

Figure 3: Variation of the winter/summer mean $H_{g}$ values under clear-sky conditions in Athens over the period 1992-2017. The linear best-fit expressions are given by Eqs. (5a) and (5b) for all- and clear-skies, respectively. 
Table 3 gives a summary of the winter/summer trends in the $H_{g}$ time series and comparison with available results from similar studies.

The discrepancy between the present seasonal trend results and those in Kambezidis [17, 18] referring to the same period, venue and $H_{g}$ time series may be attributed to the different way of calculating the trend. In the present study, the linear regression to the data series was preferred; in Kambezidis $[17,18]$ the ITA (Innovative Trend Analysis; [33, 34]) methodology was applied. The ITA method is a qualitative process and, therefore, the two sets of results cannot really be compared quantitatively.

\subsection{Trends in $\boldsymbol{H}_{d}$}

Figure 4 shows the annual $H_{d}$ averages under alland clear-sky conditions. The linear fits to both plots show the trends of $H_{d}$ under the mentioned cloudiness. These fits have relations given by the equations:

$$
\begin{aligned}
& H_{d, a}=1682.07-0.77 \text { year } \\
& H_{d, c}=2210.76-1.03 \text { year }
\end{aligned}
$$

\begin{tabular}{|c|c|c|c|}
\hline $\begin{array}{c}\text { Season } \\
\text { (Cloudiness Conditions) }\end{array}$ & $\begin{array}{c}\text { Trend in } H_{g} \\
\% / \text { decade }\left(\mathrm{Wm}^{-2} / \text { decade }\right)\end{array}$ & Reference & Period (region) \\
\hline $\begin{array}{c}\text { winter } \\
\text { (all skies) }\end{array}$ & $-2.46(-7.11)$ & present work & 1992-2017 (Athens, Greece) \\
\hline $\begin{array}{l}\text { summer } \\
\text { (all skies) }\end{array}$ & $+1.91(+9.36)$ & & \\
\hline $\begin{array}{c}\text { winter } \\
\text { (clear skies) }\end{array}$ & $-1.99(-5.94)$ & & \\
\hline $\begin{array}{c}\text { summer } \\
\text { (clear skies) }\end{array}$ & $+2.10(+10.62)$ & & \\
\hline $\begin{array}{c}\text { winter } \\
\text { (all skies) }\end{array}$ & practically no trend & {$[17,18]$} & \\
\hline $\begin{array}{l}\text { summer } \\
\text { (all skies) }\end{array}$ & practically no trend & & \\
\hline $\begin{array}{c}\text { winter } \\
\text { (clear skies) }\end{array}$ & practically no trend & & \\
\hline $\begin{array}{c}\text { summer } \\
\text { (clear skies) }\end{array}$ & practically no trend & & \\
\hline $\begin{array}{c}\text { winter } \\
\text { (all skies) }\end{array}$ & $\begin{array}{c}?(?) \\
?(?) \\
?(?) \\
?(?) \\
?(+1.40)\end{array}$ & {$[14]$} & $\begin{array}{c}1986-2012 \text { (C. Europe) } \\
1986-2012 \text { (N. Europe) } \\
1986-2012 \text { (E. Europe) } \\
1986-2012 \text { (S. Europe) } \\
1986-2012 \text { (NW. Europe) }\end{array}$ \\
\hline $\begin{array}{l}\text { summer } \\
\text { (all skies) }\end{array}$ & $\begin{array}{c}?(+4.80) \\
\quad ?(?) \\
?(?) \\
?(+5.80) \\
?(?)\end{array}$ & & $\begin{array}{c}1986-2012 \text { (C. Europe) } \\
\text { 1986-2012 (N. Europe) } \\
1986-2012 \text { (E. Europe) } \\
\text { 1986-2012 (S. Europe) } \\
\text { 1986-2012 (NW. Europe) }\end{array}$ \\
\hline $\begin{array}{c}\text { winter } \\
\text { (all skies) }\end{array}$ & $?(-1.30)$ & [25] & $\begin{array}{c}1983-2010 \& 1994-2010 \text { (CE. } \\
\text { Europe) }\end{array}$ \\
\hline $\begin{array}{l}\text { summer } \\
\text { (all skies) }\end{array}$ & $\begin{array}{l}?(+0.40) \\
?(+2.10) \\
?(+4.30)\end{array}$ & & $\begin{array}{c}\text { 1994-2010 (CE. Europe) } \\
\text { 1983-2010 (CE. Europe) } \\
\text { 1983-2010 (Europe, excl. UK, } \\
\text { France) }\end{array}$ \\
\hline
\end{tabular}

Table 3: Trends in the Winter/Summer $\boldsymbol{H}_{g}$ Mean Values under All- and Clear-Sky Conditions from Available Studies 


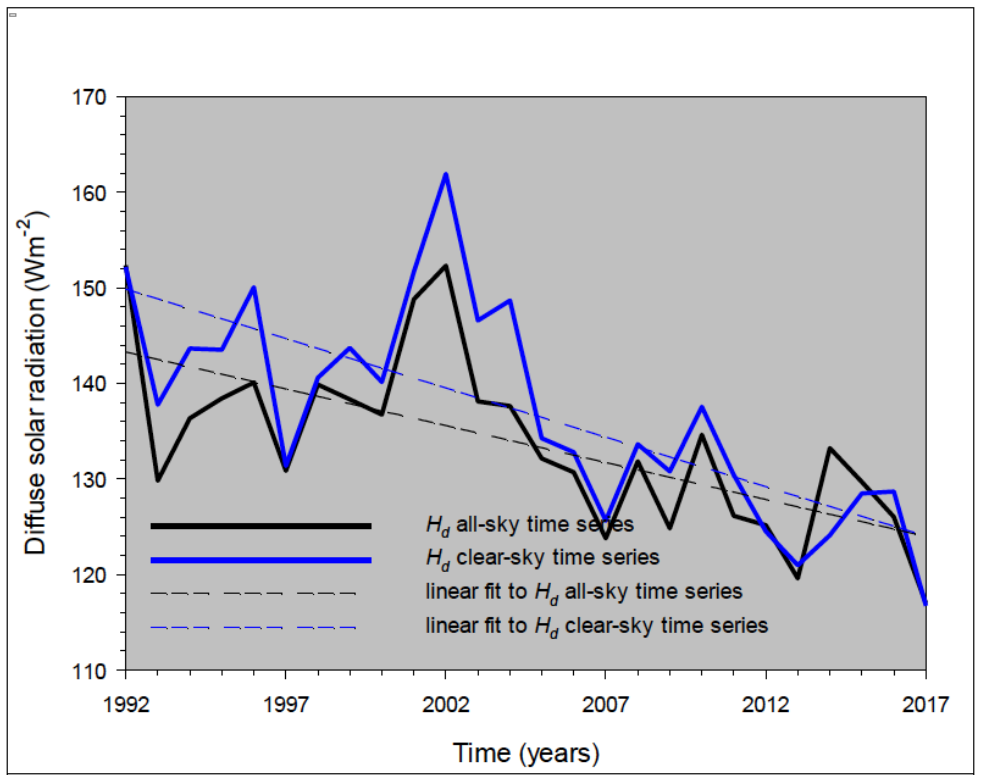

Figure 4: Variation of the annual mean $H_{d}$ values under all- and clear-sky conditions in Athens over the period 1992-2017. The linear best-fit expressions are given by Eqs. (6a) and (6b) for all- and clear-skies, respectively.

In the same way, considering the decade 19922001, applying the end years to Eq. (6a), taking the difference $H_{d, a 2001}-H_{d, a 1992}$, and dividing it by the mean $=133.64 \mathrm{Wm}^{-2}$, it is found that $H_{d}$ has a trend over the studied period of $-5.19 \% /$ decade or $\approx-0.52 \% / y e a r$. These percentages correspond to trends of $-6.93 \mathrm{Wm}^{-}$ ${ }^{2} /$ decade or $\approx-0.69 \mathrm{Wm}^{-2} /$ year, respectively, if the average $=133.64 \mathrm{Wm}^{-2}$ is taken into account. For the case of clear skies, the trends become $-6.77 \% /$ decade $(\approx-0.68 \%$ /year $)$ and $-9.27 \mathrm{Wm}^{-2} /$ decade $\left(\approx-0.93 \mathrm{Wm}^{-}\right.$ ${ }^{2} /$ year), if it is taken into account that $=136.94 \mathrm{Wm}^{-2}$. This decline in $H_{d}$ under clear skies in the Athens area after 1992 may be attributed to a decline in the cloud optical depth (COD) over the Eastern Mediterranean (especially for low-level clouds [15]). Moreover, Floutsi et al. [35] found a decline of $-1.30 \%$ in the precipitation amount over the Mediterranean during 2002-2014, "indicating a possible decline in convection and lowlevel cloudiness". In addition, Founda et al. [36] found a $+3.00 \%$ increase in the annual sunshine duration values in the period 1983-2011 in the Athens area, a finding that supports the decline in COD.

A straightforward comparison of the all- and clearsky trend results in $H_{d}$ of this work cannot be made as similar studies do not almost exist in the literature apart from the work of Kambezidis [17, 18] who found same results. This gap in knowledge is probably due to a worldwide scarcity of $H_{d}$ measurements because of expensive purchase and maintenance of solar platforms.
Figure 5 shows the seasonal (winter/summer) trend of $H_{d}$ under all-sky conditions over Athens during the period of the study. The linear fits to both plots show the seasonal trends of $H_{d}$ under the mentioned cloudiness. These fits are given by the expressions:

$H_{d, a, w}=1087.83-0.48$ year

$H_{d, a, s}=2405.12-1.13$ year

By applying the mentioned $H_{g}$ calculations to $H_{d}$, it is found that the winter trend in $H_{d}$ is $-3.18 \% / d e c a d e$ ( $\approx-$ $0.32 \%$ /year), or $-4.25 \mathrm{Wm}^{-2} /$ decade $\left(\approx-0.43 \mathrm{Wm}^{-2} /\right.$ year $)$, if the mean $=133.61 \mathrm{Wm}^{-2}$ is taken into account in the calculations. For summer, the above results become $7.60 \% /$ decade $\left(-0.76 \% /\right.$ year), and $-10.17 \mathrm{Wm}^{-2} /$ decade $\left(\approx-1.02 \mathrm{Wm}^{-2} /\right.$ year $)$, respectively. Note that $=133.86$ $\mathrm{Wm}^{-2}$

Figure 6 shows the seasonal (winter/summer) trend of $H_{d}$ under clear-sky conditions over Athens in the period 1992-2017. The linear fits to both plots show the seasonal trends in $H_{d}$ under the mentioned cloudiness. These best fits are given by the equations:

$H_{d, c, w}=1305.32-0.58$ year
$H_{d, c, s}=2471.72-1.16$ year

By repeating the known calculations as for $H_{d}$ clear skies, it is found that the winter trend in $H_{d}$ is $3.83 \% /$ decade $(-0.38 \% / y e a r)$, or $-5.22 \mathrm{Wm}^{-2} /$ decade ($0.52 \mathrm{Wm}^{-2} /$ year $)$, if the mean $=136.22 \mathrm{Wm}^{-2}$ is taken 


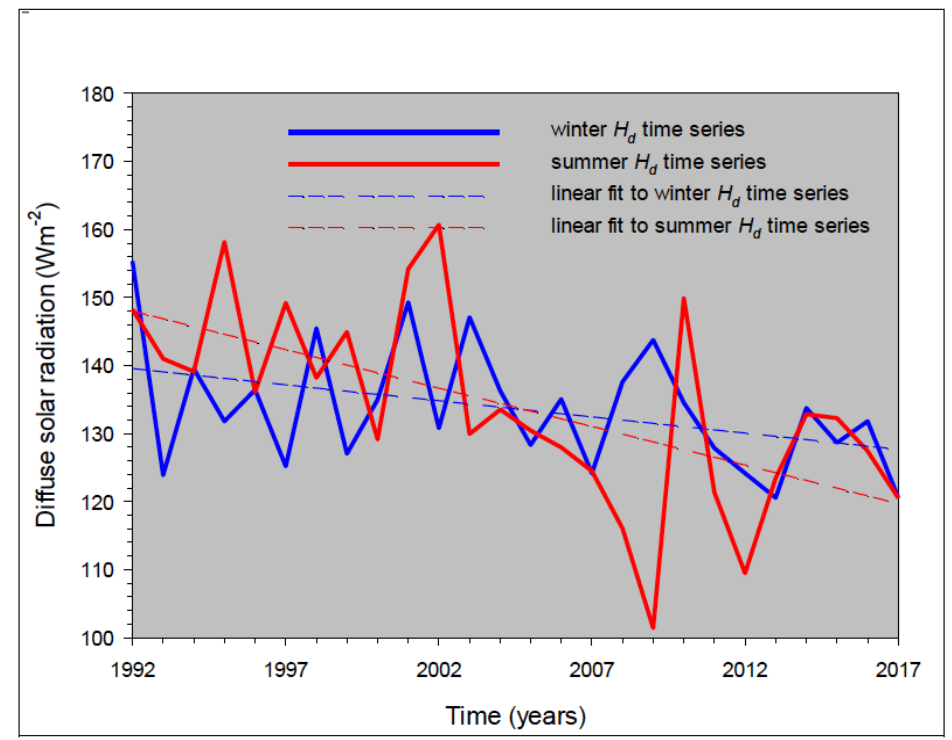

Figure 5: Variation of the seasonal mean $H_{d}$ values under all-sky conditions in Athens over the period 1992-2017. The linear best-fit expressions are given by Eqs. (7a) and (7b) for winter and summer, respectively.

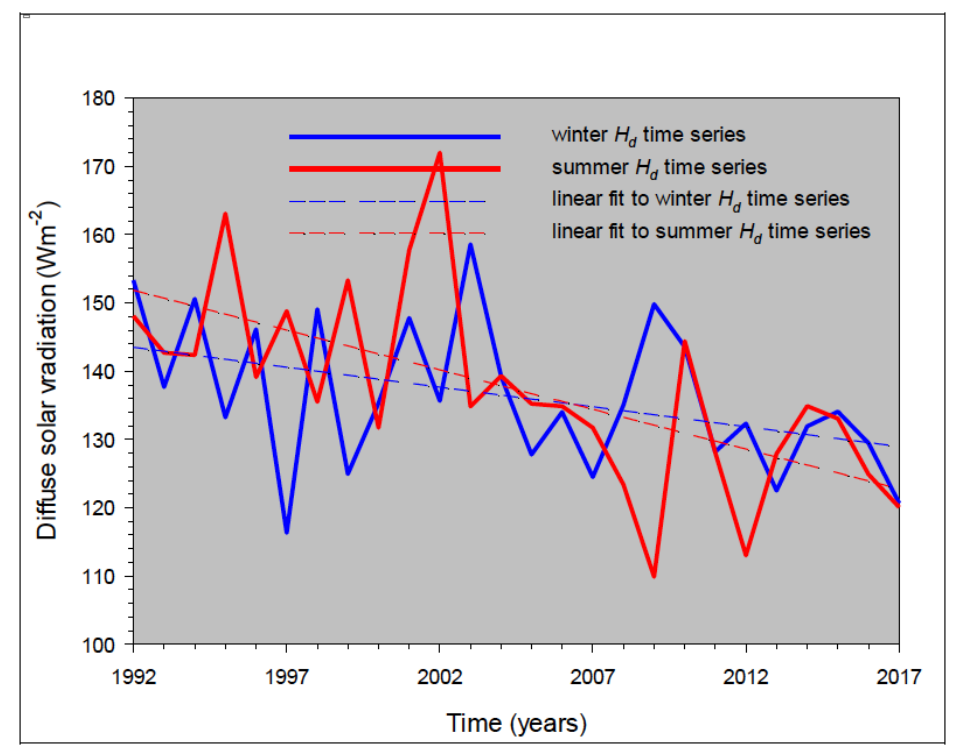

Figure 6: Variation of the seasonal mean $H_{d}$ values under clear-sky conditions in Athens over the period 1992-2017. The linear best-fit expressions are given by Eqs. (8a) and (8b) for winter and summer, respectively.

into account in the calculations. The summer calculations lead to a trend of $-7.60 \% /$ decade $(-.76 \% / y e a r)$, and $-10.44 \mathrm{Wm}^{-2} /$ decade $\left(-1.04 \mathrm{Wm}^{-}\right.$ $2 /$ year), respectively. Note that $=137.30 \mathrm{Wm}^{-2}$.

Comparison of the seasonal trends in the diffuse solar irradiance with other from similar studies do not really exist in the international literature, as it is known up to now. The only attempt was made by Kambezidis $[17,18]$. Table 4 , therefore, gives the comparison between the present study and that by Kambezidis $[17,18]$.
From the above Table it is seen that the qualitative results of Kambezidis [17, 18] are in a better agreement with those of the present work for $H_{d}$ than for $H_{g}$ (see Table 3)

\section{CONCLUSIONS}

The present study investigated the variations and trends in two solar radiation components (global, diffuse) on horizontal surface over Athens in the period 1992-2017. The main conclusions of this work can be summarised in the following. 
Table 4: Trends in the Winter/Summer $\boldsymbol{H}_{d}$ Mean Values under All- and Clear-Sky Conditions from Available Studies

\begin{tabular}{|c|c|c|c|}
\hline $\begin{array}{c}\text { Season } \\
\text { (Cloudiness Conditions) }\end{array}$ & $\begin{array}{c}\text { Trend in } H_{d} \\
\% / \text { Decade }\left(\mathrm{Wm}^{-2} / \text { Decade }\right)\end{array}$ & Reference & Period (Region) \\
\hline $\begin{array}{c}\text { winter } \\
\text { (all skies) }\end{array}$ & $-3.18(-4.25)$ & present work & 1992-2017 (Athens, Greece) \\
\hline $\begin{array}{l}\text { summer } \\
\text { (all skies) }\end{array}$ & $-7.60(-10.17)$ & & \\
\hline $\begin{array}{c}\text { winter } \\
\text { (clear skies) }\end{array}$ & $-3.83(-5.22)$ & & \\
\hline $\begin{array}{c}\text { summer } \\
\text { (clear skies) }\end{array}$ & $-7.60(-10.44)$ & & \\
\hline $\begin{array}{c}\text { winter } \\
\text { (all skies) }\end{array}$ & slight negative trend & {$[17,18]$} & \\
\hline $\begin{array}{l}\text { summer } \\
\text { (all skies) }\end{array}$ & very significant negative trend & & \\
\hline $\begin{array}{c}\text { winter } \\
\text { (clear skies) }\end{array}$ & significant negative trend & & \\
\hline $\begin{array}{c}\text { summer } \\
\text { (clear skies) }\end{array}$ & very significant negative trend & & \\
\hline
\end{tabular}

To examine the annual solar radiation trends, application of a linear regression to the deseasonalised annual mean global/diffuse radiation values was made. In any type of skies, the analysis gave a positive trend of $+0.40 \%$ /decade $\left(+1.53 \mathrm{Wm}^{-2} /\right.$ decade $)$ for $H_{g}$ and a negative trend of $-5.19 \% /$ decade $\left(-6.93 \mathrm{Wm}^{-2} /\right.$ decade $)$ for $H_{d}$.

Repetition of the above methodology for the seasonal trends to the two solar radiation components was made; for all-sky conditions, the analysis showed a winter trend for $H_{g}$ of $-2.46 \% /$ decade $\left(-7.11 \mathrm{Wm}^{-}\right.$ ${ }^{2} /$ decade) and a summer one of $+1.85 \% /$ decade $(+9.36$ $\mathrm{Wm}^{-2} /$ decade). For clear skies, the winter trend became $-1.99 \% /$ decade $\left(-5.94 \mathrm{Wm}^{-2} /\right.$ decade $)$ and the summer one $+2.10 \% /$ decade $\left(+10.62 \mathrm{Wm}^{-2} /\right.$ decade $)$. The corresponding values for the diffuse solar component were as follows. All skies: winter trend of $3.18 \% /$ decade $\left(-4.25 \mathrm{Wm}^{-2} /\right.$ decade $)$, summer trend of $7.60 \%\left(-10.17 \mathrm{Wm}^{-2} /\right.$ decade). Clear skies: winter trend of $-3.83 \% /$ decade $\left(-5.22 \mathrm{Wm}^{-2} /\right.$ decade $)$, summer trend of $-7.60 \%\left(-10.44 \mathrm{Wm}^{-2} /\right.$ decade $)$.

The above trend values show that these are all negative for $H_{d}$ in both seasons, while for $H_{g}$ it is negative in winter and positive in summer. These results clearly indicate a recovery in solar radiation levels over Athens in the period 1992-2017 (brightening effect) after a reduction in prior years [7, 37, 39]. Especially in the case of $H_{d}$, this negative trend may be attributed to a decline in COD over the Eastern Mediterranean [15].
A recent study on the reconstruction of $A O D$ values over Romania in the period 1961-2015 [38] confirms the results of the present work. Particularly, these researchers state, "These reconstructed AOD time series reveal an upward trend in AOD until mid-1980s, followed by a downward trend until the present". Indeed, the decrease in AOD in the period 1992-2017 over the Balkans can be related to an increase in clearsky solar radiation. As a matter of fact, the brightening effect over the Mediterranean, the Balkans and Southern/Eastern Europe has been verified by many relevant studies $[2,9,14-16,23,26-28,31]$.

\section{ACKNOWLEDGMENTS}

The author acknowledges the contribution of Dr. B.E. Psiloglou to the maintenance of the ASNOA solar equipment, and Dr. D.H. Founda and Mr. F. Pierros to the quality-control processing and storage of the ASNOA solar radiation data. All three are personnel of the Institute of Environmental Research and Sustainable Development, National Observatory of Athens.

\section{REFERENCES}

[1] Giesen RH, Van den Broeke MR, Oerlemans J, Andreassen LM. 2008. Surface energy balance in the ablation zone of Midtdalsbreen, a glacier in southern Norway: interannual variability and the effect of clouds. J Geophys Res 2008; 113, D21111.

https://doi.org/10.1029/2008JD010390 
[2] Asaf D, Rotenberg E, Tatarinov F, Dicken U, Montzka SA, Dan Y. Ecosystem photosynthesis inferred from measurements of carbonyl sulfide flux. Nat Geosci 2013; 3: 186-190.

https://doi.org/10.1038/ngeo1730

[3] Bojinski S, Verstraete M, Peterson TC, Richter C, Simmons A, Zemp M. The concept of essential climate variables in support of climate research, applications, and policy. Bull Am Meteorol Soc 2014; 95(9): 1431-1443.

https://doi.org/10.1175/BAMS-D-13-00047.1

[4] Kambezidis HD. Current trends in solar radiation modelling: The paradigm of MRM. J Fund Renew Energy App 2016; $6(2)$.

https://doi.org/10.4172/2090-4541.1000e106

[5] Forster P, Ramaswamy V, Artaxo P, Berntsen T, Betts R, Fahey DW, Haywood J, Lean J, Lowe DC, Myhre G, Nganga J, Prinn R, Raga G, Schulz M, Van Dorland R. 2007. Changes in Atmospheric Constituents and in Radiative Forcing. In: Climate Change 2007: The Physical Science Basis. Contribution of Working Group I to the Fourth Assessment Report of the Intergovernmental Panel on Climate Change [Solomon S, Qin D, Manning M, Chen Z, Marquis $M$, Averyt KB, Tignor $M$, Miller $H L$ (eds.)]. Cambridge University Press, Cambridge, United Kingdom and New York, NY, USA.

[6] Haywood J, Boucher O. Estimates of the direct and indirect radiative forcing due to tropospheric aerosols: A review. Rev Geophys 2000; 38: 513-543.

https://doi.org/10.1029/1999RG000078

[7] Wild M. 2009. Global dimming and brightening: a review. J Geophys Res 2009; 114, D00D16. https://doi.org/10.1029/2008JD011470

[8] Haywood JM, Bellouin N, Jones A, Boucher O, Wild M, Shine $\mathrm{KP}$. The roles of aerosol, water vapor and cloud in future global dimming/brightening. J Geophys Res 2011; 116, D20203.

https://doi.org/10.1029/2011JD016000

[9] Norris JR, Wild M. Trends in aerosol radiative effects over Europe inferred from observed cloud cover, solar "dimming" and solar "brightening." J Geophys Res 2007; 112, D08214. https://doi.org/10.1029/2006JD007794

[10] Wild $M$, Trüssel $B$, Ohmura A, Long $C N$, König-Langlo $G$, Dutton EG, Tsvetkov A. Global dimming and brightening: An update beyond 2000. J Geophys Res 2009; 114, D00D13, https://doi.org/10.1029/2008JD011382

[11] Badarinath KVS, Sharma AR, Kaskaoutis DG, Kharol SK, Kambezidis HD. Solar dimming over a tropical urban region of Hyderabad, India: effect of increased cloudiness and increased anthropogenic aerosols. J Geophys Res 2010; 115, D21208. https://doi.org/10.1029/2009JD013694

[12] Kambezidis HD, Kaskaoutis DG, Kharol SK, Moorthy KK, Satheesh SK, Kalapureddy MCR, Badarinath KVS, Sharma $A R$, Wild M. Multi-decadal variation of the net downward shortwave radiation over south Asia: The solar dimming effect. Atmos Environ 2012; 50: 360-372. https://doi.org/10.1016/j.atmosenv.2011.11.008

[13] Tang W-J, Yang K, Qin J, Cheng CCK, He J. Solar radiation trend across China in recent decades: a revisit with qualitycontrolled data. Atmos Chem Phys 2011; 11: 393-406. https://doi.org/10.5194/acp-11-393-2011

[14] Sanchez-Lorenzo A, Wild M, Brunetti M, Guijarro JA, Hakuba MZ, Calbó J, Mystakidis S, Bartok B. Re-assessment and update of long-term trends in downward surface shortwave radiation over Europe (1939-2012). J Geophys Res. Atmos 2015; 120: 9555-9569. https://doi.org/10.1002/2015JD023321

[15] Kambezidis HD, Kaskaoutis DG, Kalliampakos GK, Rashki A, Wild M. The solar dimming/brightening effect over the Mediterranean basin in the period 1979-2012. J Atmos Solar-
Terr Phys 2016; 150: 31-46. https://doi.org/10.1016/j.jastp.2016.10.006

[16] Kazadzis S, Founda D, Psiloglou BE, Kambezidis $H$, Mihalopoulos N, Sanchez-Lorenzo A, Meleti Ch, Raptis PI, Pierros $F$, Nabat $P$. Long-term series and trends in surface solar radiation in Athens, Greece. Atmos Phys Chem 2018; 18: 2395-2411, doi:10.194/acp-18-2395-2018.

[17] Kambezidis HD. The solar radiation climate of Athens: variations and tendencies in the period 1992-2017, the brightening era. Solar Energy 2018; 173: 328-347. https://doi.org/10.1016/j.solener.2018.07.076

[18] Kambezidis HD. A look at the solar radiation climate in Athens during the brightening period. Science Trends 2018; 11 September 2018, https://sciencetrends.com/a-look-at-thesolar-radiation-climate-in-athens-during-the-brighteningperiod/.

[19] Iqbal M. An introduction to solar radiation. Academic Press: Canada 1983, ISBN: 978-0-12-373750-2.

[20] Kopp G, Lean JL. A new, lower value of total solar irradiance: evidence and climate significance. Geophys Res Lett 2011; 38: L01706. https://doi.org/10.1029/2010GL045777

[21] Spencer JW. Fourier series representation of the position of the Sun. Search 1971; 2(5): 172.

[22] Kambezidis HD, Psiloglou BE, Gueymard C. Measurements and models for total solar irradiance on inclined surface in Athens, Greece. Solar Energy 1994; 53(2): 177-185. https://doi.org/10.1016/0038-092X(94)90479-0

[23] Bais A, Drosoglou T, Meleti C, Tourpali K, Kouremeti N. Changes in surface shortwave solar irradiance from 1993 to 2011 at Thessaloniki (Greece). Int J Climatol 2013; 33: 28712876.

https://doi.org/10.1002/joc.3636

[24] Boers R, Brandsma T, Siebesma AP. Impact of aerosols and clouds on decadal trends in all radiation over Netherlands (1966-2015). Atmos Chem Phys 2017; 17: 8081-8100. https://doi.org/10.5194/acp-17-8081-2017

[25] Sanchez-Lorenzo A, Enriquez-Alonso A, Wild M. Trends in downward surface solar radiation from satellites and ground observations over Europe during 1983-2010. Rem Sens Environ 2017; 189: 108-117. https://doi.org/10.1016/j.rse.2016.11.018

[26] Alexandri G, Georgoulias AK, Meleti C, Balis D, Kourtidis KA Sanchez-Lorenzo A, Trentmann J, Zanis P. A high-resolution satellite view of surface solar radiation over the climatically sensitive region of Eastern Mediterranean. Atmos Res 2017; 188: 107-121, doi:10.1016/j/atmosres.2016.12.015.

[27] Nabat $P$, Somot S, Mallet M, Sanchez-Lorenzo A, Wild M. Contribution of anthropogenic sulfate aerosols to the changing Euro-Mediterranean climate since 1980. Geophys Res Lett 2014; 41

\section{https://doi.org/10.1002/2014GL060798}

[28] Manara V, Brunetti M, Celozzi A, Maugeri M, SanchezLorenzo A, Wild M. Detection of dimming/brightening in Italy from homogenized all-sky and c;lear-sky surface radiation records and underlying causes (1959-2013). Atmos Chem Phys 2016; 16: 11145-11161, doi:10.5194/acp-16-11145206.

[29] Manara V, Bassi M, Brunetti M, Cagnazzi B, Maugeri M. 1990-2016 surface solar radiation variability and trend over the Peidmont region (Northwest Italy). Theor Appl Climatol 2018.

https://doi.org/10.1007/s00704-018-2521-6

[30] Pfeiforth U, Kothe S, Müller R, Trentmann J, Hollmann R, Fuchs $\mathrm{P}$, Werscheck $M$. Surface radiation data set Heliostat (SARAH) - Edition 2. Satellite Appl. Facility on Climate Monitoring 2017; doi:10.5676/EUM_SAF_CM/SARAH/V002.

[31] Pfeifroth U, Sanchez-Lorenzo A, Manara V, Trentmann J, 
Hollmann R. Trends and variability of surface solar radiation in Europe based on surface- and satellite-based data records. J Geophys Res Atmos 2018; 123. https://doi.org/10.1002/2017JD027418

[32] Folini D, Wild M. Aerosol emissions and dimming/brightening in Europe: sensitivity studies with ECHAM5-HAM. J Geophys Res 2011; 116: D21104.

https://doi.org/10.1029/2011JD016227

[33] Şen Z. Innovative trend analysis methodology. J Hydrol Eng 2012; 17: 1042-1046. https://doi.org/10.1061/(ASCE)HE.1943-5584.0000556

[34] Şen Z. Innovative trend significance test and applications. Theor Appl Climatol 2015; 19: 635-642.

[35] Floutsi A., Korras-Carraca MB, Matsoukas C, Hatzianastassiou N, Biskos G. Climatology and trends of aerosol optical depth over the Mediterranean basin during the last 12 years (2002-2014) based on Collection 006 MODIS Aqua Data. Sci Total Environ 2016; 551-552: 292303.

https://doi.org/10.1016/j.scitotenv.2016.01.192
[36] Founda D, Kalimeris A, Pierros F. Multi-annual variability and climatic signal analysis of sunshine duration at a large urban area of Mediterranean (Athens). Urban Climate 2014; 10: 815-830.

https://doi.org/10.1016/j.uclim.2014.09.008

[37] Wang K, Ma Q, Wang XY, Wild M. Urban impacts on mean and trend of surface incident solar radiation. Geophys Res Lett $2014 ; 41$. https://doi.org/10.1002/2014GL060201

[38] Dumitrescu A, Gueymard CA, Badescu V. Reconstruction of historical aerosol optical depth time series over Romania during summertime. Int J Climatol 2017; 37(13): 4720-4732. https://doi.org/10.1002/joc.5118

[39] Wild M, Ohmura A, Makowski K. Impact of global dimming and brightening on global warming. Geophys Res Lett 2007; 34: L04702. https://doi.org/10.1029/2006GL028031

DOI: http://dx.doi.org/10.31875/2410-2199.2018.05.3

(c) 2018 Harry D. Kambezidis; Zeal Press.

This is an open access article licensed under the terms of the Creative Commons Attribution Non-Commercial License (http://creativecommons.org/licenses/by-nc/3.0/) which permits unrestricted, non-commercial use, distribution and reproduction in any medium, provided the work is properly cited. 